\title{
Special Issue: Contemporary Research on Early Childhood Education for Sustainability
}

\author{
Eva Ärlemalm-Hagsér ${ }^{1} \cdot$ Sue Elliott $^{2}$
}

Published online: 14 December 2017

(C) Springer Science+Business Media B.V. 2017

The first IJEC special issue on early childhood education for sustainability (ECEfS) was published in 2009. It included an article (Davis et al. 2009) about the UN set of recommendations adopted for education for sustainable development (ESD) in early childhood education, which are also titled The Gothenburg Recommendations. The 2009 special issue also included papers with themes on citizenship, globalisation, diversity, cultural relevance, policy and pedagogy, but only a few were informed by empirical research. In the editorial for the 2009 special issue, John Siraj-Blatchford (2009) noted that these papers focused on interrogating dominant economic and political thinking, promoting the three pillars of sustainability, and investigating the challenges of globalisation. Almost a decade later as global climate change has become a cause for mitigation rather than prevention, it appears more than timely for us, as guest editors, to revisit ECEfS. Our intent in this editorial is to critically reassess the journey travelled so far and propose avenues for further exploration.

We are driven by a firm belief that in early childhood education, we have an ethical responsibility to care and to act for sustainable futures for all, irrespective of the troubling political landscapes that thwart our calls for quantum global changes. In a recent compilation of articles about children and climate change, Currie and Deschenes (2016) make it patently clear that today's children will bear the brunt of climate change for years to come, their well-being and development will be negatively impacted, and global inequities for children will be exacerbated. Further, the current seventeen UN Sustainable Development Goals (SDGs) (2016)

Eva Ärlemalm-Hagsér

eva.arlemalm-hagser@mdh.se

Sue Elliott

sue.elliott@une.edu.au

1 School of Education, Culture and Communication (UKK), Mälardalen University, Västerås, Sweden

2 School of Education, University of New England, Armidale, NSW 2351, Australia 
acknowledge that approaches to sustainability must be multifaceted including quality education, health, gender equity, economic growth, peace and partnerships. In times of such complex and dynamic uncertainties for children, we argue individual and global ignorance and inaction are not an option.

While the UN Gothenburg Recommendations (UNESCO 2008) were espoused internationally by ECEfS advocates and set the scene for embracing ECEfS, internationally scaled change was minimal as reflected by the UN Decade of Education for Sustainable Development (2005-2014) Progress Report (UNESCO 2012). The report somewhat weakly stated, '...the presence of ESD in ECCE is a new development' (UNESCO 2012, p. 32). However, UNESCO subsequently published a final report entitled Shaping the Future We Want: UN Decade of Education for Sustainable Development (2005-2014) with a section devoted to ECEfS recognising, 'ECCE has a clear role in preparing present and future citizens and in aiding societies to make the necessary transitions to sustainability' (UNESCO 2014, p. 70). The report identified four foci for moving forward: deepening the research base; approaching learning in community-based and holistic ways; educating families as well as children; and implementing training for early childhood educators. There is no question these foci significantly align with philosophies and pedagogies in early childhood education and moreover, with broad systemic approaches to sustainability, multi-level coordination, engagement of diverse stakeholders and implementation of localised initiatives. These potentially groundbreaking shifts are feasible.

Notably, the first focal area of deepening the research base is now tangibly evident. In 2009, Davis identified the paucity of published ECEfS papers in a mapping review of relevant journals; some 5 years later Somerville and Williams (2015) described a doubling of published papers since Davis's (2009) earlier review. Also, the first edited compilation of ECEfS research was published (Davis and Elliott 2014). The editors highlighted the dominance of submitted chapters around curriculum and pedagogy, viewed as a reflection of the strongly practitioner-led field in ECEfS research and advocacy. This emergent publication base has been strengthened by the international meetings of Transnational Dialogues in ECEfS research which have occurred on four occasions since 2010 (Emery et al. 2017). These international gatherings have forged research and publication collaborations and promoted dialogues at many levels across diverse contexts. There is a perennial shared dialogue about the gaps, challenges and tensions in ECEfS research and practice experienced across the globe.

The growing body of ECEfS research literature from different theoretical and methodological perspectives (Ärlemalm-Hagsér and Davis 2014; Davis and Elliott 2014; Green 2015; Somerville and Williams 2015) suggests there are several research areas still to be developed: (1) critical studies; (2) education contexts; (3) transformational pedagogies; and (4) ECEfS theoretical concepts and understandings.

Firstly, critical studies refer to research that acknowledges the dominant structures of hegemonic thinking and acting and the traditions and understandings constituted in historical, social and cultural contexts (Alvesson and Sköldberg 2009). For example, Kopina (2017) stresses the need for critical SDG studies to 
examine how an ecocentric philosophy embracing multispecies perspectives and cross-cultural sensitivities may be applied in education. Raus and Veli-Matti (2017) highlight assumptions, embedded anthropocentric thinking and dualistic concepts of human/non-human in Western metaphysics and the need for analysing teachers and student teachers 'ecological self' (Ärlemalm-Hagsér 2013; Elliott and Young 2015). Another perspective for critical examination is how social, ecological and economic sustainability incorporating children's participation and agency resonates with early childhood education in a neoliberal agenda as individualism, self-realisation and self-governance, as well as consumerism (Raby 2014).

Secondly, in education contexts there is a need to engage in research about how sustainability is understood and enacted alongside competing views of daily realities. Research to date has identified both a knowledge-practice gap and rhetoric-reality gap for practitioners (Elliott et al. 2016; Dyment et al. 2014). We question how educators and children could learn together to make EfS mainstream in their contexts, rather than ad hoc targeted activities (Ärlemalm-Hagsér and Sundberg 2016). Additionally, what competencies are required at different levels within education contexts to promote multi-dimensional understandings of sustainability (Sterling et al. 2017)? We argue teacher educators and pre-service students in higher education (Ferreira et al. 2014, 2015) must understand EfS, and, in the field, ongoing professional learning is pivotal to how early childhood educators think about and enact EfS.

Thirdly, there is a significant call for studies of transformational pedagogies through multiple and holistic approaches in higher education (Higgins and Thomas 2016); and especially, in pre-service teacher education (Ferreira et al. 2015). Studies that scrutinise institutional cultures both in universities and early education settings and seek to disrupt thinking and co-construct new pedagogies and knowledges are required. Furthermore, scrutiny is needed into how collaborative educational spaces that promote a participatory paradigm and empower ethics could be constructed (Sterling et al. 2017). As well as scrutiny into how, and which, transformational pedagogies could be explicitly developed to enhance EfS among educators, for example, 'learning to be leaders for culture change' (Ferreira et al. 2015).

Fourthly, as a relatively new field of research there is a significant need for developing and deepening a range of theoretical frames from different ontological and empirical perspectives. Davis $(2014,2015)$, for example, advocates for an expanded rights framework including: (1) children's competence and right to participate in sustainability efforts; (2) children's right to be agents of change; (3) collective rights, as a complement to thinking about children's/human rights; (4) intergenerational rights; and (5) the rights of all living beings as well the non-living. Somerville and Williams (2015) suggest that employing a post-humanist framework and a philosophy beyond the nature-culture binary can be one way to discursively challenge unsustainable epistemologies, ontologies and practices. Also, values as well as cultural-historical ideas and philosophies are deeply intertwined with everyday pedagogy (Dahlberg and Moss 2005). Ärlemalm-Hagsér and Elliott (2017) argue the need for different theoretical and methodological perspectives to construct children, childhood and early childhood education in particular ways and contribute to our knowledge of relationships between children, nature and culture. 
In summary, we advocate for ongoing research that may examine the hidden conditions and structures that reproduce unsustainable and inequitable thinking, acting and policies in ECE. In this special edition of IJEC, we are pleased to share a collation of nine papers that begin to address our concerns for ECEfS and promote directions for research in order move forward.

The first paper How to Educate Children for Sustainable Learning in a Sustainable World (Pramling-Samuelsson and Park) broadly sets the scene drawing on current policy to address how values related to sustainability promote certain pedagogies and how such pedagogies support early learning about EfS. The following two papers (Ritchie and Green) bring into play Indigenous worldviews or ontologies building localised eco-cultural literacies and developing environmental identities in the respective and diverse contexts of Aotearoa (New Zealand) and Alaska, USA. In the next paper, O'Gorman delves into the ethical issues involved in the implementation of a research study that employed artist Chris Jordan's confronting images about sustainability with young children. The arts can be both a confronting and compelling vehicle for provoking change. When co-authors from diverse contexts research write together in this emergent research field, the comparative challenges and rewards are evident. The two papers by co-author teams (Weldemariam et al. and Inoue et al.), when combined, deliver ECEfS insights about curriculum and pedagogy from Japan, Korea, England, Sweden, Norway, Australia and the USA. The paper from Weldemariam et al. focusses on a comparative analysis of curriculum documents, while Inoue et al. compare educator understandings and practices in EfS. The final three papers explore issues in early years and school settings, and pre-service teacher education. Elliot and Krusekopf narrate their journey into building a nature kindergarten approach, in which children spend half of every school day outdoors, with a group of children and their teachers in the first year of school in Canada, Lasen et al. examine teacher perceptions and practices of EfS in the early years in an Australian primary school setting, while Ärlemalm-Hagsér focusses on Swedish pre-service teacher ECEfS in practicum settings.

We acknowledge the support of IJEC Editor, Donna Berthelsen, in bringing this special issue to fruition and trust that future guest editors will be well-positioned to report significant shifts in ontological and theoretical frames, and pedagogical practice in ECEfS. To not achieve this goal would be to fail generations of children.

\section{References}

Alvesson, M., \& Sköldberg, K. (2009). Reflexive methodology. New vistas for qualitative research. Los Angeles: SAGE.

Ärlemalm-Hagsér, E. (2013). 'An interest in the best for the world'? Education for sustainability in the Swedish preschool. (Doctoral Thesis, Gothenburg Studies in Educational Sciences 335). Gothenburg: Acta Universitatis Gothoburgensis.

Ärlemalm-Hagsér, E., \& Davis, J. (2014). Examining the rhetoric: A comparison of how sustainability and young children's participation and agency are framed in Australian and Swedish early childhood education curricula. Contemporary Issues in Early Childhood, 15(3), 231-244. 
Ärlemalm-Hagsér, E., \& Elliott, S. (2017). Transcultural differences in the development of nature orientated early education. In P. Becker, C. Loynes, B. Humberstone, \& J. Schirp (Eds.), The changing world of the outdoors: European reflexions. London \& New York: Routledge Falmer.

Ärlemalm-Hagsér, E., \& Sundberg, B. (2016). Nature experiences and recycling: A quantitative study on education for sustainable development in Swedish preschools. Nordina, 12(2), 140-156.

Currie, J., \& Deschenes, O. (2016). Children and climate change: Introducing the issue. The Future of Children, 26(1), 3-9.

Dahlberg, G., \& Moss, P. (2005). Ethics and politics in early childhood education. Routledge Falmer: London \& New York.

Davis, J. (2009). Revealing the research "hole", of early childhood education for sustainability: A preliminary survey of the literature. Environmental Education Research, 15(2), 227-241.

Davis, J. (2014). Examining early childhood education through the lens of education for sustainability: Revisioning rights. In J. Davis \& S. Elliott (Eds.), Research in early childhood education for sustainability: International perspectives and provocations (pp. 21-37). London: Routledge.

Davis, J. (Ed.). (2015). Young children and the environment: Early education for sustainability (2nd ed.). Port Melbourne: Cambridge University Press.

Davis, J., \& Elliott, S. (2014). Research in early childhood education for sustainability: International perspectives and provocations. London: Routledge.

Davis, J., Engdahl, I., Otieno, L., Pramling-Samuelsson, I., Siraj-Blatchford, J., \& Vallabh, P. (2009). Early childhood education for sustainability: Recommendations for development. International Journal of Early Childhood, 41(2), 113-117.

Dyment, J., Davis, J., Nailon, D., Emery, S., Getenet, S., McCrea, N., et al. (2014). The impact of professional development on early childhood educators' confidence, understanding and knowledge of education for sustainability. Environmental Education Research, 20(5), 660-679.

Elliott, S., McCrea, N., Newsome, L., \& Gaul, J. (2016). Examining environmental education in NSW early childhood education services: A literature review with findings from the field. Sydney: NSW $\mathrm{OEH}$ Environmental Trust. Retrieved from http://www.environment.nsw.gov.au/grants/ dissemination.htm.

Elliott, S., \& Young, T. (2015). Nature by default in early childhood education for sustainability. Australian Journal of Environmental Education. doi:10.1017/aee.2015.44.

Emery, S., Davis, J., Sageidet, B. M., Hirst, N., Boyd, D., \& Browder, J. K. (2017). Transnational dialogues for sustainability research in early childhood education: A model for building capacity for ESD in universities? In W. Leal Filho, L. Brandli, P. Castro, \& J. Newman (Eds.), Handbook of theory and practice of sustainable development in higher education. World Sustainability Series (pp. 143-156). Berlin: Springer.

Ferreira, J., Ryan, E., \& Davis, J. (2015). Developing knowledge and leadership in pre-service teacher education systems. Australian Journal of Environmental Education, 31(2), 194-207.

Ferreira, J., Ryan, L., \& Tilbury, D. (2014). A response to reorienting teacher education towards sustainability. Australian Journal of Environmental Education, 30(1), 147-148.

Green, C. (2015). Toward young children as active researchers: A critical review of the methodologies and methods in early childhood environmental education. Journal of Environmental Education, 46(4), 207-229.

Higgins, B., \& Thomas, I. (2016). Education for sustainability in universities: Challenges and opportunities for change. Australian Journal of Environmental Education, 32(1), 91-108.

Kopina, H. (2017). Future scenarios for sustainability education: The future we want? In P. Blaze Corcoran, J. Weakland, \& A. Wals (Eds.), Envisioning futures for environmental and sustainability education (pp. 129-140). Wageningen: Wageningen Academic Publishers.

Raby, R. (2014). Children's participation as neo-liberal governance? Discourse: Studies in the Cultural Politics of Education, 35(1), 77-89.

Raus, R., \& Veli-Matti, V. (2017). Teacher ecological self-an ontological journey towards transformative sustainability. In P. Blaze Corcoran, J. Weakland, \& A. Wals (Eds.), Envisioning futures for environmental and sustainability education (pp. 103-116). Wageningen: Wageningen Academic Publishers.

Siraj-Blatchford, J. (2009). Editorial: Education for sustainable development in early childhood. International Journal of Early Childhood, 41(2), 9-22.

Somerville, M., \& Williams, C. (2015). Sustainability education in early childhood: An updated review of research in the field. Contemporary Issues in Early Childhood, 16(2), 102-217. 
Sterling, S., Glasser, H., Rieckmann, M., \& Warwick, P. (2017). "More than scaling up": A critical and practical inquiry into operationalizing sustainability competences. In P. Blaze Corcoran, J. Weakland, \& A. Wals (Eds.), Envisioning futures for environmental and sustainability education (pp. 153-168). Wageningen: Wageningen Academic Publishers.

UNESCO. (2008). The Gothenburg Recommendations on Education for Sustainable Development. Paris: UNESCO.

UNESCO. (2012). UN Decade of Education for Sustainable Development (DESD 2005-2014) Progress Report. Paris: UNESCO.

UNESCO. (2014). Shaping the future we want: UN Decade of Education for Sustainable Development (2005-2014) Final Report. Paris: UNESCO.

United Nations (UN). (2016). The sustainable development goals report 2016. New York: United Nations. Retrieved from https://unstats.un.org/sdgs/report/2016. 